\title{
Effects of one year's treatment with ranitidine and of truncal vagotomy on gastric contents
}

\author{
J MEYRICK THOMAS, J J MISIEWICZ, A R COOK, M J HILL, P L R SMITH, \\ C L WALTERS, J K FORSTER, L E MARTIN, AND D F WOODINGS
}

From the Department of Gastroenterology and Nutrition, Central Middlesex Hospital, London, PHLS Centre for Applied Microbiology and Research, Porton Down, Salisbury, Wiltshire, The British Food Manufacturing Industries Research Association, Leatherhead, Surrey, and Glaxo Group Research Ltd., Ware, Herts.

SUMMARY Fifteen patients with peptic ulcer underwent 24 hour studies of gastric contents: before and on completing six weeks' treatment with oral ranitidine $150 \mathrm{mg}$ bd, twice on maintenance treatment for nine to 12 months and one month after stopping the drug. For comparison, 11 patients underwent identical 24 hour studies three to 38 months after truncal vagotomy for duodenal ulcer. During treatment with ranitidine median 24 hour intragastric $\mathrm{pH}$, nitrate concentration, and counts of total and nitrate reducing bacteria increased significantly regardless of dietary nitrate content; there was no significant increase in the median day time concentration of $\mathrm{N}$-nitroso compounds. Despite these changes, an acid tide at some point in each 24 hour study period prevented persistent bacterial colonisation of the stomach. There were no significant differences between the biochemical and microbiological changes recorded during one year of treatment with ranitidine, and the observations on patients after truncal vagotomy. One month after stopping one year's treatment with ranitidine all variables examined returned to pretreatment levels. Treatment with ranitidine or vagotomy was associated with significant positive correlations among $\mathrm{pH}$, nitrate concentration and bacterial counts. Correlations between $\mathrm{pH}$ and $\mathrm{N}$-nitroso compound concentration and between concentrations of nitrite and $\mathrm{N}$-nitroso compounds were not significant.

Pernicious anaemia; $;^{1-3}$ partial gastrectomy, ${ }^{4-6}$ and vagotomy ${ }^{7-9}$ appear to be associated with increased risk of gastric cancer. The exact cause is unknown but a hypothetical sequence of events necessary for the development of gastric cancer in hypochlorhydric states has been postulated "11 and depends on the persistence within the stomach at $\mathrm{pH}>4.0$ of metabolically active bacteria capable of reducing dietary nitrate to nitrate. Nitrate may then react with amides or amines to form $\mathrm{N}$-nitroso compounds, most of which are carcinogenic to animals. Concern has been expressed about a similar carcinogenic potential arising from medical treatment of ulcer using potent acid lowering drugs such as the histamine $\mathrm{H}_{2}$ receptor antagonists, particularly when treatment is prolonged in prophylaxis against ulcer recurrence. Studies of fasting gastric juice have suggested

Address for correspondence: Mr J Meyrick Thomas, Department of Surgery, Royal Free Hospital, Pond Street. Hampstead, London NW3 2QG.

Received for publication 10 October 1986. increased bacterial counts and concentrations of nitrite $^{12-14}$ and $\mathrm{N}$-nitroso compounds during treatment with cimetidine..$^{12-13}$ Hourly sampling of gastric contents throughout 24 hour periods ( 24 hour studies) before, during and after short term treatment with cimetidine of healthy volunteers ${ }^{15}$ and patients with duodenal ulcer, ${ }^{16}$ however, using an alternative method for determining $\mathrm{N}$-nitroso compound concentrations, has not shown significant changes in these variables.

Ranitidine, a more potent histamine $\mathrm{H}_{2}$-antagonist than cimetidine,${ }^{17}$ is widely used in the treatment of peptic ulcer disease. It is effective in the short term treatment of duodenal ulcer ${ }^{1819}$ and is also highly effective in the maintenance therapy of this disease. ${ }^{21}{ }^{21}$ Maintenance treatment of duodenal ulcer with histamine $\mathrm{H}_{2}$-antagonists is likely to become increasingly preferred to elective surgery for patients whose ulcers recur after short term healing, if it can be shown to be free from serious unwanted effects. 
There have been no previous studies of the way prolonged histamine $\mathrm{H}_{2}$-receptor blockade changes the intragastric environment. In this study the effect of one year's continuous treatment with ranitidine of patients with healed duodenal or gastric ulcer has been compared with the effect of truncal vagotomy. The variables investigated included intragastric acidity, bacteriology of gastric juice and of gastric biopsies and biochemistry of gastric juice with respect to nitrate, nitrite and $\mathrm{N}$-nitroso compounds. Patients were studied before, during and after medical treatment and after truncal vagotomy.

\section{Methods}

\section{PATIENTS}

RANITIDINE TREATMENT GROUP

Fifteen patients with ulcer disease (Table 1) were investigated on up to five occasions by 24 hour studies (R): $R_{1}$ within one week of endoscopic diagnosis and before starting treatment with ranitidine $150 \mathrm{mg}$ twice daily given at 0900 and $2100 \mathrm{~h}$ with minimum antacid tablets necessary for control of symptoms; $\mathbf{R}_{\mathbf{2}}$ immediately before the end of six weeks' treatment with ranitidine; $R_{3}$ after three months' maintenance treatment with ranitidine $150 \mathrm{mg}$ nightly at $2100 \mathrm{~h}$; $\mathrm{R}_{4}$ immediately before completing nine to 12 months' maintenance treatment; $R_{5}$ one month after stopping treatment with ranitidine (Fig. 1). Before each 24 hour study ulcer healing/non-recurrence was confirmed endoscopically.

\section{Ranitidine group}

\begin{tabular}{|c|c|c|c|c|c|}
\hline Pre treatment & $\begin{array}{l}\text { After } 6 \\
\text { weeks treatment } \\
\text { (Ranitidine } \\
150 \mathrm{mg} \text { b.d.) }\end{array}$ & $\begin{array}{l}\text { After } 3 \\
\text { months treatment } \\
\text { (Ranitidine } \\
150 \text { mg nocte ) }\end{array}$ & $\begin{array}{l}\text { After } 9-12 \\
\text { months treatment } \\
\text { (Ranitidine } \\
150 \text { mg nocte ) }\end{array}$ & $\begin{array}{l}1 \text { month } \\
\text { after stopping } \\
\text { treatment }\end{array}$ & $\begin{array}{l}\text { Atter } \\
\text { vagotomy }\end{array}$ \\
\hline $\begin{array}{l}24 \text { hour } R_{1} \\
\text { study }\end{array}$ & $R_{2}$ & $R_{3}$ & $R_{4}$ & $\mathrm{R}_{5}$ & \\
\hline
\end{tabular}

Statistical comparisons between studies
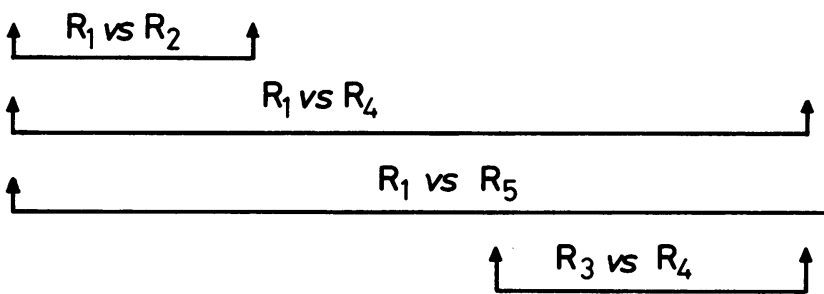

$$
R_{4} \text { vs post-vagotomy }
$$

Fig. 1 Study design detailing times of studies $R_{I}-R_{5}$ carried out on patients in the ranitidine group and comparisons made between studies.
Table 1 Details of patients studied (ranitidine group)

\begin{tabular}{lllll}
\hline Patient & $\begin{array}{l}\text { Age \& } \\
\text { sex }\end{array}$ & Diagnosis & Cigs/day & $\begin{array}{l}\text { Beer } \\
\text { pints/day }\end{array}$ \\
\hline 1 & $49 \mathrm{M}$ & DU & Nil & 1 \\
2 & $68 \mathrm{M}$ & DU & Nil & Nil \\
3 & $69 \mathrm{M}$ & DU & Nil & Nil \\
4 & $69 \mathrm{M}$ & GU & Nil & Nil \\
5 & $48 \mathrm{M}$ & PyU & 30 & 1 \\
6 & $53 \mathrm{M}$ & GU & 15 & Nil \\
7 & $63 \mathrm{M}$ & DU & Nil & $1 / 2$ \\
8 & $68 \mathrm{M}$ & GU & 10 & Nil \\
9 & $46^{*} \mathrm{M}$ & DU & 10 & 2 \\
10 & $49^{*} \mathrm{M}$ & DU \& PyU & Nil & 2 \\
11 & $54^{*} \mathrm{M}$ & GU & 25 & 3 \\
12 & $50^{*} \mathrm{M}$ & DU & Nil & $1 / 2$ \\
13 & $39^{*} \mathrm{M}$ & PyU & 15 & $\mathrm{Nil}$ \\
14 & $57^{*} \mathrm{M}$ & GU & 10 & $1 / 2$ \\
15 & $44^{*} \mathrm{M}$ & DU & 10 & 1 \\
\hline
\end{tabular}

Mean age $55(\mathrm{SD}=10$ years $)$; $\mathrm{DU}=$ duodenal ulcer; $\mathrm{GU}=$ gastric ulcer; $\mathrm{PyU}=$ juxtapyloric ulcer. ${ }^{*}=$ High nitrate diet during studies

\section{VAGOTOMY GROUP}

even patients had 24 hour studies (Table 2): eight (patients V1, V6, and V9, Table 2) were studied immediately before and three months after truncal vagotomy and pyloroplasty. The 24 hour study technique was identical to that used in the ranitidine treatment group. Completeness of vagotomy was first established in all the patients studied by applying strict criteria for Hollander tests done within two vagotomy and pyloroplasty and the other three 
Table 2 Details of patients studied (vagotomy group)

\begin{tabular}{lllll}
\hline Patient & $\begin{array}{l}\text { Age \& } \\
\text { sex }\end{array}$ & Diagnosis & Cigs/day & $\begin{array}{l}\text { Beer } \\
\text { pints/day }\end{array}$ \\
\hline V1 & $+45^{*} \mathrm{M}$ & DU & 20 & 1 \\
V2 & $43^{*} \mathrm{M}$ & DU & 10 & Nil \\
V3 & $48 \mathrm{M}$ & DU & 15 & 1 \\
V4 & $54 \mathrm{M}$ & DU & Nil & $1 / 2$ \\
V5 & $50 \mathrm{~F}$ & DU & Nil & Nil \\
V6 & $+44 \mathrm{~F}$ & DU & 10 & Nil \\
V7 & $56^{*} \mathrm{M}$ & DU & Nil & 4 \\
V8 & $58^{*} \mathrm{M}$ & DU & 15 & Nil \\
V9 & $+40^{*} \mathrm{M}$ & DU & 25 & 7 \\
V10 & $58 \mathrm{~F}$ & DU & 10 & Nil \\
V11 & $41^{*} \mathrm{M}$ & DU & 20 & 3 \\
\hline
\end{tabular}

Mean age $49\left(\mathrm{SD}=7\right.$ years); ${ }^{*}=$ High nitrate diet (during studies); $\dagger=$ Also studied preoperatively.

months of 24 hour studies. (Peak acid output $<3.58 \mathrm{mmol} / \mathrm{h}$ and $30-120$ minute acid output $<2.55 \mathrm{mmol} / \mathrm{h}$ after intravenous Actrapid insulin $0 \cdot 15 \mathrm{U} / \mathrm{kg}){ }^{22}$

All patients studied agreed in writing to take part in the investigation, which was approved by the hospital ethical committee.

\section{DIET}

All patients ate identical meals at identical times (Figs. 3-7) during all 24 hour studies. Food (Table 3), with the exception of milk, was bought in bulk at the beginning of the investigation and stored dry, or deep frozen to minimise variation in content. Foods and beverages (including beer) which are rich in nitrate or $\mathrm{N}$-nitroso compounds were avoided on study days but, to ensure an adequate nitrate intake, half of the patients (seven ranitidine, six vagotomy) received additional nitrate $300 \mathrm{mg}$ per study (high nitrate diet - Tables 1 and 2) added as sodium nitrate $150 \mathrm{mg}$ $(1765 \mu \mathrm{mol})$ during reconstitution of instant mashed potato at lunch and dinner. No attempt was̀ made to control patients' diet between studies. The basic diet contained $47 \mathrm{mg}$ nitrate ( $553 \mu \mathrm{mol}$ as sodium nitrate) in dry solids and, on average, $48 \mathrm{mg}(565 \mu \mathrm{mol})$ in liquids (drinking water concentration of nitrate varied from undetectable to $500 \mu \mathrm{mol} / \mathrm{l})$. Neither nitrite nor $\mathrm{N}$-nitroso compounds were detectable in either solid or liquid fractions of the diet, with the exception of nitrite in drinking water (concentration varied from undetectable to $180 \mu \mathrm{mol} / \mathrm{l})$.

Nitrate, nitrite and N-nitroso compound content of the liquid fraction of the diet and of drinking water consumed at each study were measured using the same methods as those used for gastric juice (see below). The contents of the solid fraction of the diet were determined by suspending the 24 hour food solids in water and homogenising; nitrate and nitrite content were then determined by reduction to nitro-
Table 3 Composition of 24 hour study menu

\begin{tabular}{|c|c|c|}
\hline 0900 & Breakfast & $\begin{array}{l}\text { Cornflakes with milk and sugar } \\
\text { Toast ( } 2 \text { slices) with butter and } \\
\text { marmalade } \\
\text { Tea or coffee* }\end{array}$ \\
\hline 1100 & Mid-morning snack & $\begin{array}{l}\text { Biscuits }(2) \\
\text { Tea or coffee }\end{array}$ \\
\hline 1300 & Lunch & $\begin{array}{l}\text { Cottage pie } \\
\text { Croquette potatoes } \\
\text { Peas } \\
\text { Treacle tart } \\
\text { Glass of orange squash }\end{array}$ \\
\hline 1600 & Afternoon snack & $\begin{array}{l}\text { Biscuits }(2) \\
\text { Tea or coffee }\end{array}$ \\
\hline 1900 & Dinner & $\begin{array}{l}\text { Chicken pie } \\
\text { Instant mashed potato } \\
\text { Peas } \\
\text { Fruit salad (tinned) } \\
\text { Glass of orange squash }\end{array}$ \\
\hline 2200 & Late-night snack & $\begin{array}{l}\text { Biscuits (3) with butter and cheese } \\
\text { Tea or coffee* }\end{array}$ \\
\hline
\end{tabular}

*Each patient decided at the first study which beverage, and how many cups to drink at each meal and kept to this choice in all subsequent studies.

gen oxide (analysed by chemiluminescence) using modifications of the method of Cox. ${ }^{23}$ Nitrate was reduced by refluxing in a $50 \%(\mathrm{v} / \mathrm{v})$ mixture of concentrated sulphuric acid and water containing ferrous ammonium sulphate and ammonium molybdate; reduction of nitrite was achieved by refluxing in a mixture of $0.2 \mathrm{M}$ sodium iodide solution $(25 \% \mathrm{v} / \mathrm{v})$ and glacial acetic acid (75\% v/v). N-nitroso compound content was established by adding $10 \%$ (w/v) sodium chloride and extracting three times with ethyl acetate (stored over sulfamic acid to destroy nitrite) before applying the sequential procedure of Walters et al ${ }^{24}$ (see below).

Patients who smoked consumed their habitual number of cigarettes during 24 hour studies (Table 1), the same number of cigarettes being smoked at the same times during each study by each smoking patient.

\section{EXPERIMENTAL PROCEDURE}

Each 24 hour study started at $0800 \mathrm{~h}$ with the positioning of an indwelling Salem sump nasogastric tube (14 French gauge) after taking a throat swab to document resident oropharyngeal flora. Recovery of fasting gastric juice indicated satisfactory tube positioning; if fasting juice could not be aspirated the tube was repositioned using fluoroscopic screening. Samples of gastric juice were aspirated at hourly intervals from $1200-2100 \mathrm{~h}$ and from $2400-0900 \mathrm{~h}$ by manual suction: the three hour periods between 09 00-1200 h (study $R_{2}$ ) and 2100-2400 h (studies $\mathbf{R}_{2-4}$ ) were avoided to prevent aspiration of unabsorbed ranitidine. The aspirates were divided for microbiological analysis (counts of total bacteria (TB) and nitrate-reducing bacteria (NRB)) and for 


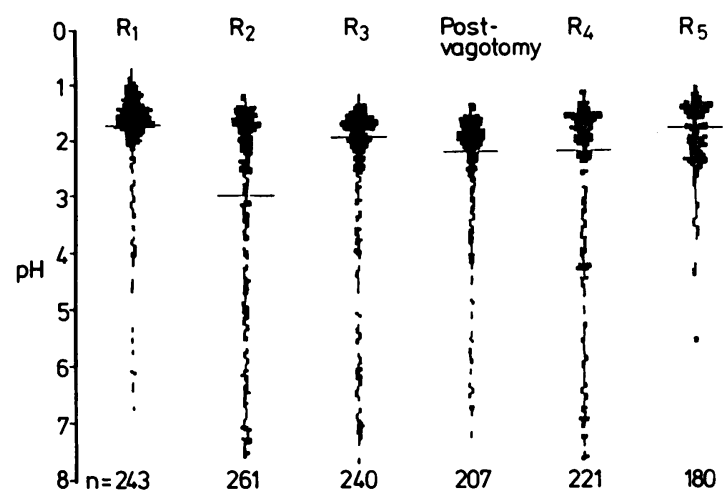

Fig. 2
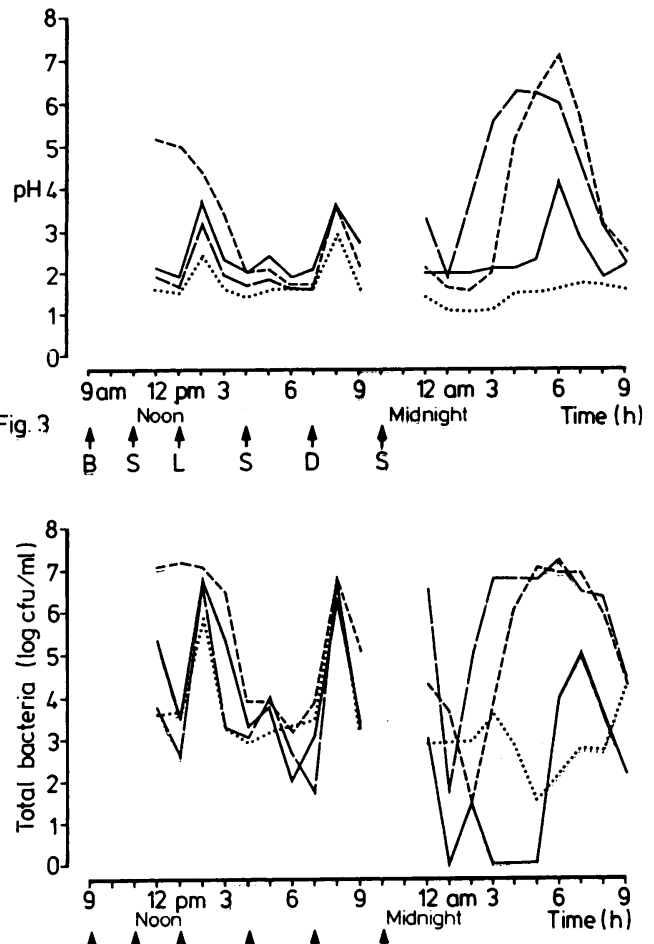

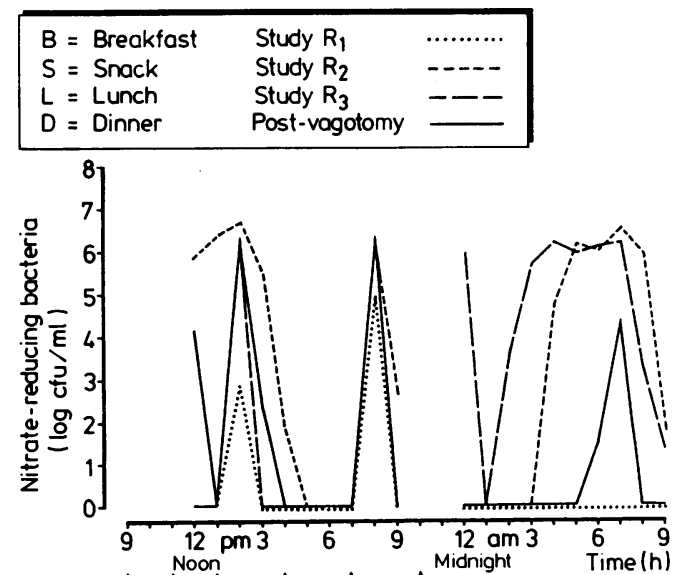

Fig. 5 B $\stackrel{4}{S} \stackrel{4}{\text { Noon }}$ \&
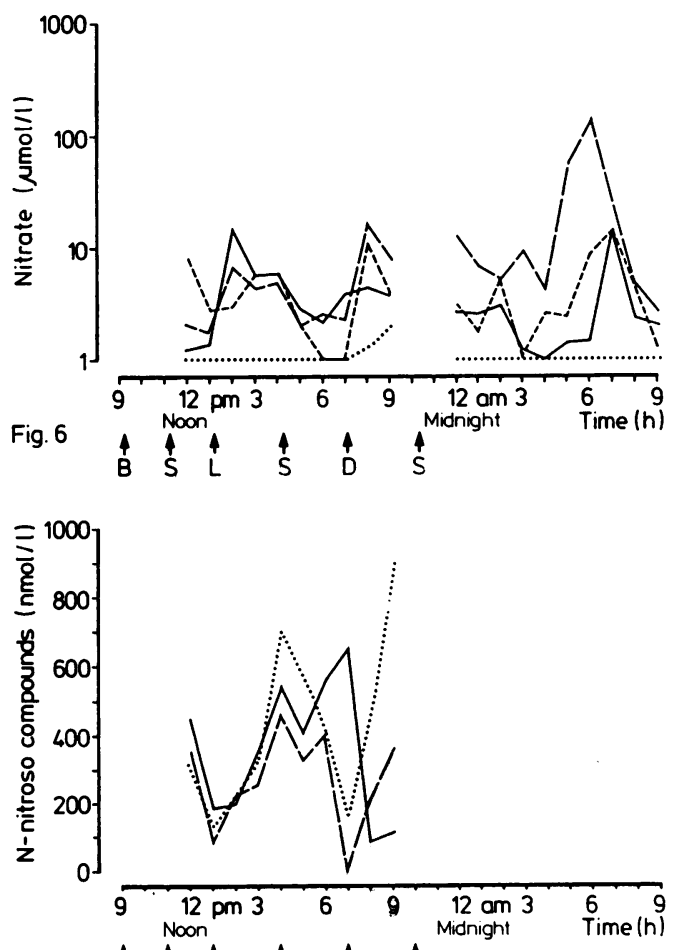

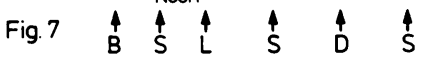

Fig. 2 Distribution of all pH recordings made in studies Horizontal bar represents median value for each study.

Figs. 3-7 Median hourly $\mathrm{pH}$, bacterial counts and concentrations of nitrate and $\mathrm{N}$-nitrosocompounds during 24 hour studies $B=$ Breakfast $\boldsymbol{S}=$ Snack; $L=$ Lunch $\boldsymbol{D}=$ Dinner; Study $R_{1} \ldots \ldots$. Study $R_{2}----;$ Study $R_{4}-$ - post-vagotomy -

determination of $\mathrm{pH}$, nitrate, nitrite and $\mathrm{N}$-nitroso compound concentrations.

During the 24 hour studies patients remained in suitable accommodation in the Department of Gastroenterology, where they were closely super- vised, but free to move at will within the department. Atmospheric settle plates were exposed in the patients' living area, kitchen and the laboratory to record the environmental bacterial flora for later comparison with patients' oropharyngeal and gastric flora. 
MICROBIOLOGY

Immediately after aspiration each sample of gastric juice was homogenised in a sterile plastic envelope using a Stomacher laboratory blender (Seward Laboratory); an $0.5 \mathrm{ml}$ aliquot was diluted 10 -fold into brain heart infusion broth and transferred immediately to a custom built portable anaerobic cabinet ${ }^{25}$ in a room adjacent to the patients' living area. The anaerobic atmosphere used was $80 \%$ nitrogen: $10 \%$ hydrogen: $10 \%$ carbon dioxide; the cabinet contained a palladium catalyst and silica gel crystals to maintain an oxygen free environment.

Replicate 10 -fold dilutions were prepared into microtitre wells containing indole nitrite as an indicator of nitrate reductase activity ${ }^{26}$ and stored in anaerobic containers before removal from the cabinet. After three days' anaerobic incubation, the wells were read for growth and nitrate reduction. Using the technique of most probable number analysis, ${ }^{27}$ estimates of TB and NRB counts were obtained. Lower limit of detection was 10 colony forming units $/ \mathrm{ml}$.

A further $0.5 \mathrm{ml}$ aliquot of homogenised gastric juice was diluted into glycerol transport broth, frozen immediately at $-80^{\circ} \mathrm{C}$ and maintained at $-40^{\circ} \mathrm{C}$ before later thawing and inoculation on a range of selective and non-selective media maintained in aerobic, anaerobic and microaerophilic environments for identification of bacterial genera. Throat swabs taken at the start of each study were inoculated immediately into glycerol transport broth, frozen, stored, then thawed and cultured in the same way.

PH

$\mathrm{pH}$ of the gastric aspirates was measured immediately after homogenisation using a combined glass electrode (Russell pH Ltd) in conjunction with a digital $\mathrm{pH}$ meter and auto-titration assembly (Radiometer, Copenhagen). The electrode was calibrated at laboratory temperature at the beginning of each study using buffers of $\mathrm{pH} 2 \cdot 01$ (Merck), 4.01 and 7.00 (Radiometer). Calibration was checked and adjusted if necessary, at four to six hourly intervals throughout each 24 hour study, taking account of any change in ambient temperature.

\section{NITRITE}

Homogenised gastric juice samples (diluted if necessary with distilled water to a final volume of $5 \cdot 0$ $\mathrm{ml}$ ) were titrated to $\mathrm{pH} 8.0$ with molar sodium hydroxide and frozen at $-10^{\circ} \mathrm{C}$ before deproteinisation, decolourising and spectrophotometric assay at $\lambda 530 \mathrm{~nm}$ (Unicam, Cambridge) using a modified sulphanilamide diazotisation reaction. "' Lower limit of detection was $1.0 \mu \mathrm{mol} / \mathrm{l}$.

\section{NITRATE}

Nitrate concentration was measured by conversion of nitrate to nitrite in vitro by incubation of samples with Escherichia coli nitrate reductase suspension ${ }^{28}$ and subsequent assay as nitrite (by the above method). Lower limit of detection was $5 \mu \mathrm{mol} / \mathrm{l}$.

\section{N-NITROSO COMPOUNDS}

When sufficient gastric juice was present, samples for estimation of $\mathrm{N}$-nitroso compound were collected hourly between 1200 and $2100 \mathrm{~h}$ in studies $R_{1}, R_{3}$, $\mathbf{R}_{\mathbf{4}}$, and $\mathbf{R}_{\mathbf{5}}$ and after vagotomy. In all samples studied ranitidine was undetectable by radioimmunoassay ${ }^{29}$ with a lower limit of detection at $20 \mathrm{ng}$ of ranitidine/ $\mathrm{ml}$.

$\mathrm{N}$-nitroso compounds were assayed by measurement of nitrogen oxide evolved under special conditions. ${ }^{24}$ The assays were restricted to ranitidine free samples because the presence of ranitidine in gastric juice may result in falsely high concentrations of $\mathrm{N}$ nitroso compounds being recorded. Unlike cimetidine, the ranitidine molecule contains a C-terminal nitro group which was shown in preliminary studies to liberate nitrogen oxide under conditions of the assay, thus responding as if it were an $\mathrm{N}$-nitroso compound.

After preliminary dilution, if necessary, to $5.0 \mathrm{ml}$ with distilled water, homogenised gastric juice samples were titrated (if $\mathrm{pH}<4$ ) to $\mathrm{pH} 4.0$ with molar sodium hydroxide and hydrazine sulphate $(0 \cdot 26 \mathrm{M})$ was added to destroy any nitrite present, before freezing to $-10^{\circ} \mathrm{C}$ for later assay using the method of Walters et al. ${ }^{24}$ This method responds sensitively to all types of $\mathrm{N}$-nitroso compounds tested to date: it involves the controlled evolution of nitrogen oxide sequentially from a range of compounds present in gastric juice when refluxed with ethyl acetate. After the addition of acetic acid, nitrogen oxide is liberated initially from nitrate and other compounds derived from it, such as the pseudonitrosites, and finally, when hydrogen bromide is added, denitrosation occurs yielding nitrogen oxide from $\mathrm{N}$-nitroso compounds. Thus, nitrogen oxide originating from other types of compounds is eliminated before it is evolved from $\mathrm{N}$-nitroso compounds. Nitrogen oxide was determined using a chemiluminescence analyser by the light emitted in the far visible and near infra red regions after its reaction with ozone. The lower limit of detection was approximately $5 \mathrm{nmol} / 1$.

STATISTICAL ANALYSIS

Data pertaining to $\mathrm{pH}$, nitrite and $\mathrm{N}$-nitroso compound concentrations and bacterial counts (TB and NRB) were summarised for each 24 hour study in each patient using median values. The median was used because it gives an average value which can 
accommodate responses recorded as less than the lower limit of detection. An overall summary value of each variable for a given study was calculated by taking the median of individual patient's median values during that study. Observations were also summarised for each patient as the percentage of samples in each study with values greater than a predetermined, clinically meaningful cut off level, provided that results from at least 10 of the possible 20 samples (1200-2100 h and 2400-0900 h) were available. For $\mathrm{N}$-nitroso compounds the period 1200-2100 was similarly summarised provided that values from at least five of the 10 possible samples were available. The median of these percentages was used for each variable to summarise all patients' data during each study.

The predetermined cut-off levels were selected as follows: for intragastric acidity, $\mathrm{pH} 4.0$ was selected, because intragastric bacteria do not survive below this $\mathrm{pH} .{ }^{30}$ For bacterial studies $10^{5}$ colony forming units $(\mathrm{cfu}) / \mathrm{ml}$ was chosen, because this is the generally accepted level of bacterial counts indicating established and persisting bacterial multiplication. ${ }^{31}$ For biochemical data, nitrite $10 \mu \mathrm{mol} / \mathrm{l}$ was chosen, as this concentration was shown by Jones $e a^{l^{22}}$ to distinguish between patients with normal or dysplastic gastric mucosa and thus seemed appropriate to this study. For N-nitroso compounds the critical level selected was $500 \mu \mathrm{mol} / \mathrm{l}$ as the only published data suggest that this is the upper limit of normality for the $\mathrm{N}$-nitroso compound content of fasting gastric juice. ${ }^{33}$

In study $\mathbf{R}_{\mathbf{4}}$ and in the vagotomy group the nocturnal period $2400-0900 \mathrm{~h}$ was analysed separately for $\mathrm{pH}$ and other variables in addition to the 24 hour analysis. This was done to compare the effects of the two treatment modalities on nocturnal acidity and gastric juice composition. The variables under study were summarised as median values and percentages of samples above adopted cut off levels.

Within patient comparisons between studies (summarised in Fig. 1) were made using two sided sign tests as, although it was usually possible to determine the direction of change of a response, the magnitude of the change could not be calculated using values which were known only to be less than the lower limit of detection. In the ranitidine group, study $R_{1}$ was compared with studies $R_{2}, R_{4}$, and $R_{5}$ and study $\mathbf{R}_{\mathbf{3}}$ was compared with $\mathbf{R}_{\mathbf{4}}$.

The effects of long term medical and surgical treatment were compared by applying the two-sided Wilcoxon's rank-sum-test to study $\mathbf{R}_{\mathbf{4}}$ of the ranitidine group and to the postoperative study of the vagotomy group for 24 hour summary data and also for night-time samples alone. Formal statistical evaluation of the effect of truncal vagotomy and pyloroplasty (by comparing summary values before and after vagotomy) was not possible because only three patients were studied preoperatively.

The effect of the high nitrate diet was assessed by applying Fisher's exact test to the proportion of ranitidine treated patients in the two dietary sub groups whose median values for each variable increased between studies $R_{1}$ and $R_{4}$.

Correlations between variables were assessed as follows. Associations were investigated between $\mathrm{pH}$ and TB counts, between $\mathrm{pH}$ and NRB counts, between $\mathrm{pH}$ and nitrite concentrations, between $\mathrm{pH}$ and $\mathrm{N}$-nitroso compound concentrations and between nitrite and $\mathrm{N}$-nitroso compound concentrations. The associations were measured separately for the ranitidine treatment group of patients and for the vagotomy group by means of Kendall's rank correlation coefficients. These coefficients were calculated for each patient, in the case of the ranitidine group after pooling the data from the five studies. Each resulting set of correlation coefficients was subjected to the two sided sign test to assess the statistical power of any overall association. Each set is represented for convenience, but not for implied mathematical significance, by its median value $\left(r_{\text {median }}\right)$.

\section{Results}

\section{PATIENTS}

The ranitidine group comprised 15 men aged 39-69 years (mean 55) (Table 1) and the vagotomy group eight men and three women aged $40-58$ years (mean 49) (Table 2).

Endoscopy confirmed symptomatic ulcer recurrence in patients 5 and 15 at study $R_{3}$ : ulcers were healed again after taking ranitidine $150 \mathrm{mg}$ twice daily for six weeks, starting the day following study $R_{3}$. These two patients also relapsed at study $R_{4}$ and were treated with sucralfate (a drug without known effects on gastric acidity) $1 \mathrm{G}$ four times daily until 24 hours before they underwent study $R_{5}$ (when endoscopy confirmed rehealing of ulcers).

Three patients in the ranitidine group were withdrawn before study $R_{3}$ (Table 1 ): patient 3 died of myocardial infarction, patient 14 died of bronchial carcinoma and chronic granulocytic leukaemia and patient 11 underwent radical distal partial gastrectomy when biopsy disclosed gastric carcinoma. He had an apparently benign gastric ulcer one year previously which healed after treatment with tripotassium dicitratobismuthate; carcinoma was diagnosed after a total of 40 biopsies and five sets of cytology brushings, none of which had indicated malignancy. One patient defaulted from study $\mathbf{R}_{5}$ because of business commitments and one patient missed studies $R_{3}$ and $R_{5}$ for personal reasons. Apart 
Table 4 Biochemical and bacteriological 24 hours summary data (1200-2100h for nitrosocompounds)

\begin{tabular}{|c|c|c|c|c|c|c|}
\hline & $\begin{array}{l}\text { Ranitidine } \\
R_{1}[n=15]\end{array}$ & $\begin{array}{l}\text { Ranitidine } \\
R_{2}\lfloor n=15]\end{array}$ & $\begin{array}{l}\text { Ranitidine } \\
R_{3}[n=13]\end{array}$ & $\begin{array}{l}\text { Postvagotomy } \\
{[n=11]}\end{array}$ & $\begin{array}{l}\text { Ranitidine } \\
R_{\mathbf{4}}[n=12]\end{array}$ & $\begin{array}{l}\text { Ranitidine } \\
R_{5}[n=10]\end{array}$ \\
\hline Median pH & $\begin{array}{l}1 \cdot 7 \\
(1 \cdot 0-3 \cdot 3)\end{array}$ & $\begin{array}{l}3 \cdot 0 \\
(1 \cdot 6-6 \cdot 3)\end{array}$ & $\begin{array}{l}2 \cdot 0 \\
(1 \cdot 6-5 \cdot 0)\end{array}$ & $\begin{array}{l}2 \cdot 2 \\
(1 \cdot 6-4 \cdot 2)\end{array}$ & $\begin{array}{l}2 \cdot 2 \\
(1 \cdot 6-5 \cdot 5)\end{array}$ & $\begin{array}{l}1 \cdot 8 \\
(1 \cdot 4-2 \cdot 5)\end{array}$ \\
\hline$\%$ samples $\mathrm{pH}>4$ & $\begin{array}{l}0 \\
(0-29)\end{array}$ & $\begin{array}{l}30 \\
(5-95)\end{array}$ & $\begin{array}{l}20 \\
(0-55)\end{array}$ & $\begin{array}{l}15 \\
(0-63)\end{array}$ & $\begin{array}{l}23 \\
(0-70)\end{array}$ & $\begin{array}{l}0 \\
(0-12)\end{array}$ \\
\hline $\begin{array}{l}\text { Median total bacteria } \\
\log _{10} \mathrm{cfu} / \mathrm{ml}\end{array}$ & $\begin{array}{l}3 \cdot 0 \\
(<1 \cdot 0-6 \cdot 9)\end{array}$ & $\begin{array}{l}6 \cdot 4 \\
(<1 \cdot 0-8 \cdot 0)\end{array}$ & $\begin{array}{l}4 \cdot 3 \\
(2 \cdot 4-6 \cdot 8)\end{array}$ & $\begin{array}{l}3 \cdot 4 \\
(<1 \cdot 0-6 \cdot 8)\end{array}$ & $\begin{array}{l}3 \cdot 4 \\
(<1 \cdot 0-7 \cdot 3)\end{array}$ & $\begin{array}{l}2 \cdot 4 \\
(<1 \cdot 0-4 \cdot 5)\end{array}$ \\
\hline $\begin{array}{l}\text { Median NRB } \\
\log _{10} \mathrm{cfu} / \mathrm{ml}\end{array}$ & $\begin{array}{l}<1 \cdot 0 \\
(<1 \cdot 0-6 \cdot 8)\end{array}$ & $\begin{array}{l}5 \cdot 3 \\
(<1 \cdot 0-7 \cdot 5)\end{array}$ & $\begin{array}{l}<1 \cdot 0 \\
(<1 \cdot 0-6 \cdot 1)\end{array}$ & $\begin{array}{l}<1 \cdot 0 \\
(<1 \cdot 0-6 \cdot 0)\end{array}$ & $\begin{array}{l}<1 \cdot 5 \\
(<1 \cdot 0-6 \cdot 2)\end{array}$ & $\begin{array}{l}<1 \cdot 0 \\
(<1 \cdot 0-1 \cdot 9)\end{array}$ \\
\hline$\%$ NRB $>10^{5} \mathrm{cfu} / \mathrm{ml}$ & $\begin{array}{l}13 \\
(0-71)\end{array}$ & $\begin{array}{l}50 \\
(17-100)\end{array}$ & $\begin{array}{l}25 \\
(0-67)\end{array}$ & $\begin{array}{l}25 \\
(6-79)\end{array}$ & $\begin{array}{l}33 \\
(0-79)\end{array}$ & $\begin{array}{l}11 \\
(0-33)\end{array}$ \\
\hline $\begin{array}{l}\text { Median nitrite concn } \\
\mu \mathrm{mol} / \mathrm{l}\end{array}$ & $\begin{array}{l}<1 \cdot 3 \\
(<1 \cdot 0-4 \cdot 3)\end{array}$ & $\begin{array}{l}2 \cdot 9 \\
(<1 \cdot 0-42 \cdot 7)\end{array}$ & $\begin{array}{l}4 \cdot 2 \\
(<1 \cdot 0-43 \cdot 9)\end{array}$ & $\begin{array}{l}2 \cdot 2 \\
(1 \cdot 2-32 \cdot 8)\end{array}$ & $\begin{array}{l}5 \cdot 1 \\
(<1 \cdot 0-50 \cdot 1)\end{array}$ & $\begin{array}{l}1 \cdot 5 \\
(<1 \cdot 0-3 \cdot 6)\end{array}$ \\
\hline $\begin{array}{l}\% \text { samples nitrite concn } \\
>10 \mu \mathrm{mol} / 1\end{array}$ & $\begin{array}{l}0 \\
(0-21)\end{array}$ & $\begin{array}{l}18 \\
(0-100)\end{array}$ & $(0-75)$ & $\begin{array}{l}13 \\
(0-77)\end{array}$ & $(0-84)$ & $\begin{array}{l}3 \\
(0-21)\end{array}$ \\
\hline $\begin{array}{l}\text { Median N-nitroso compound } \\
\text { concn }(\mathrm{nmol} / \mathrm{l})\end{array}$ & $\begin{array}{l}395 \\
(<88-1355)\end{array}$ & - & $\begin{array}{l}330 \\
(126-690)\end{array}$ & $\begin{array}{l}260 \\
(<5-1430)\end{array}$ & $\begin{array}{l}253 \\
(<128-800)\end{array}$ & $\begin{array}{l}247 \\
(<58-1020)\end{array}$ \\
\hline $\begin{array}{l}\% \text { samples } \mathrm{N} \text {-nitroso compound } \\
\text { concn }>500 \mathrm{nmol} / \mathrm{l}\end{array}$ & $\begin{array}{l}43 \\
(0-80)\end{array}$ & - & $\begin{array}{l}40 \\
(20-71)\end{array}$ & $\begin{array}{l}33 \\
(0-87)\end{array}$ & $\begin{array}{l}13 \\
(0-63)\end{array}$ & $\begin{array}{l}35 \\
(0-78)\end{array}$ \\
\hline
\end{tabular}

Numbers are medians (range); cfu = colony-forming units.

from these exceptions all patients receiving ranitidine underwent all five 24 hour studies; thus 63 of a possible 75 studies were performed in this group. The duration of maintenance treatment of the 12 patients who were not withdrawn was 12 months in six patients and nine to 10 months in the remaining six. No patients in the vagotomy group were withdrawn from the study.

BIOCHEMICAL AND BACTERIOLOGICAL DATA Resuts of 24 hour studies and their statistical analysis are summarised in Tables 4 and 5 and are presented

Table 5 Summary of differences between 24 hour studies.

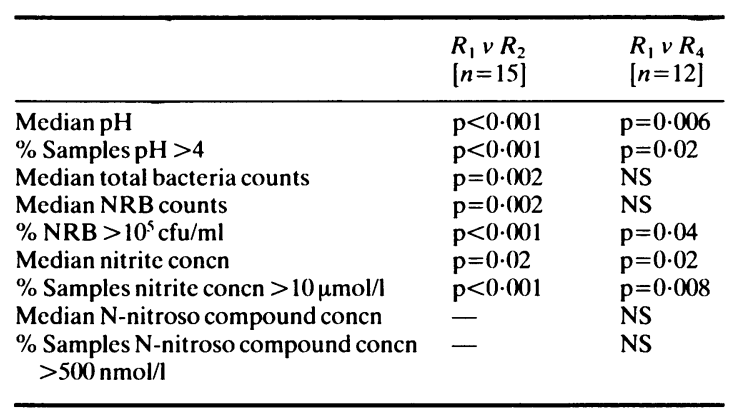

All significant results indicate values which increased from study $R_{1}$ to either study $R_{2}$ or study $R_{4} N S=$ not significant $(\mathrm{p}>0.05)$.

Comparisons of all variables between studies $R_{3}$ and $R_{4}, R_{1}$ and $\mathbf{R}_{5}, \mathbf{R}_{\mathbf{4}}$ and postvagotomy demonstrated no statistically significant differences. Night time comparison (2400-0900) between $R_{4}$ and postvagotomy showed median total bacterial counts significantly higher in $R_{4}(p=0.05)$ but no other statistically significant differences. in detail below.

Data from the 10 patients with duodenal or juxtapyloric ulcers and from the five patients with gastric ulcers (in the ranitidine treatment group) were analysed separately with respect to all the variables discussed below. The results in these two subgroups (data available on file) did not differ from results obtained when all 15 patients were combined. Data have therefore been pooled for analysis and presentation of results.

PH OF GASTRIC ASPIRATES (FIGS 2 AND 3)

The distribution of all the $\mathrm{pH}$ readings collected during each study are shown in Fig. 2 and show the expected skewness. The medians of median $\mathrm{pH}$ values of individual patients and of individual percentages of samples at $\mathrm{pH}>4.0$ increased significantly in patients treated with ranitidine from pretreatment $\left(R_{1}\right)$ to values obtained during twice daily treatment $\left(R_{2}, p<0.001\right)$ and at the end of maintenance treatment $\left(\mathrm{R}_{4}, \mathrm{p}=\mathbf{0 . 0 0 6}\right.$ for median $\mathrm{pH}, \mathrm{p}=0.02$ for $\%$ samples at $\mathrm{pH}>4 \cdot 0$ ). There was no significant difference in median $\mathrm{pH}$ values between studies $\mathrm{R}_{1}$ (before treatment) and $\mathrm{R}_{5}$ (after treatment finished). Median $\mathrm{pH}$ values after truncal vagotomy $(\mathrm{pH} 2 \cdot 2)$ was remarkably similar to that recorded in the ranitidine studies $\mathrm{R}_{\mathbf{3}}$ (median $\mathrm{pH} 2 \cdot 0$ ) and $\mathrm{R}_{\mathbf{4}}$ (median $\mathrm{pH} 2 \cdot 2)$. The percentage of gastric aspirates at $\mathrm{pH}>4.0$ was $15 \%$ in vagotomised patients compared with $20 \%$ in study $R_{3}$ and $23 \%$ in $R_{4}$. Statistical analysis showed no significant differences between the vagotomy group and study $R_{4}(p>0 \cdot 05)$.

Although inhibition of nocturnal intragastric acidity on the median $\mathrm{pH}$ plot was apparently greater 
during maintenance treatment with ranitidine (Fig. $3, \mathbf{R}_{\mathbf{4}}$ ) than in vagotomised subjects (Fig. 3, postvagotomy), statistical analysis of night-time samples did not disclose significant differences between these two treatments $(\mathrm{p}>0.05)$. Twice daily dosing with ranitidine during the healing period did not suppress nocturnal intragastric acidity further, although stomach contents were more alkaline during the early afternoon (Fig. 3, $\mathrm{R}_{2}$ ).

\section{BACTERIAL COUNTS}

Bacterial species commonly encountered in hypoacidic samples $(\mathrm{pH}>4.0)$ included oral streptococci, lactobacilli, diphtheroids, Streptococcus viridans, Bacteroides spp and the NRB Veillonellae and Staphylococcus albus. Much less commonly identified were Staphylococcus aureus, Streptococcus faecalis, Haemophilus spp, Bifidobacterium spp, Fusobacterium spp and yeasts. Although deliberately sought, Clostridia spp, Pseudomonas aeruginosa and enterococci were never seen. Throat swabs taken at the beginning of each 24 hour study yielded a mixed growth of aerobes, facultative, and obligate anaerobes. This bacterial flora was representative of airborne organisms cultured from settle plates left exposed in patients' living area, kitchen and the laboratory.

High counts $\left(10^{5}-10^{7}\right)$ of TB and NRB were found in gastric aspirates one to two hours after main meals whether or not patients were subject to medical or surgical treatment, but were only present in nocturnal aspirates, intermittently in some patients and continuously for longer or shorter periods in others, during treatment with ranitidine, or following vagotomy. Bacteria encountered always reflected the patients' resident oropharyngeal flora, which in turn reflected the bacteria isolated from atmospheric settle plates.

There were highly significant $(p=0.002)$ increases in the medians of median values of TB (Fig. 4) and NRB counts (Fig. 5) and of the percentage of samples with NRB counts $>10^{5}(p<0 \cdot 001)$ between studies $R_{1}$ and $R_{2}$. Median TB and NRB counts increased, but not significantly, in $R_{4}$ compared with $R_{1}$. However, the percentage of samples in $R_{4}$ containing NRB counts $>10^{5}$ did increase significantly $(p=0 \cdot 04)$. Bacterial counts in study $R_{1}$ were similar to, and not statistically different from those recorded in $\mathbf{R}_{5}$. Median counts of TB $\left(10^{3-4}\right)$ and NRB $(<10)$ and percentage of samples with NRB $>10^{5}(25 \%)$ after vagotomy were all similar to data recorded in the patients receiving maintenance treatment with ranitidine $\left(R_{3}\right.$ and $\left.R_{4}\right)$. Comparison between $R_{4}$ and vagotomy with respect to both 24 hour summary data and nocturnal samples alone showed no significant differences for $\mathrm{NRB}(\mathrm{p}<0 \cdot 05)$, but the difference just

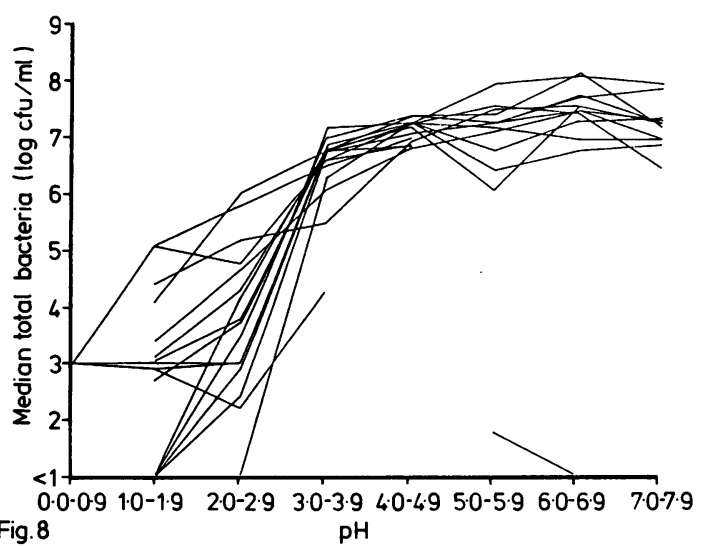

Fig. 8 Comparison between median total bacterial counts and $p H$ range of individual patients at each study $R_{I}-R_{5}$ Each line represents an individual patient. $r_{\text {median }}=0.51$ $p<0 \cdot 001$.

achieved significance overnight $(p=0 \cdot 05)$ for median counts of $T B$, which were higher in $R_{4}$.

During treatment with ranitidine and after vagotomy, $\mathrm{pH}$ correlated positively with TB counts $\left(r_{\text {median }}=0.51, p<0.001\right.$ (Fig. 8) and $r_{\text {median }}=0.43$, $\mathrm{p}<0.001$ respectively) and with NRB counts $\left(r_{\text {median }}=0.47, p<0.001\right.$ (Fig. 9) and $r_{\text {median }}=0.38$ $\mathrm{p}<0.001$ respectively).

\section{NITRATE CONCENTRATION}

The median of the median nitrite concentrations increased significantly $(p=0.02)$ from study $R_{1}$ to $R_{2}$ and $R_{4}$ as did the median percentage of samples with nitrite concentration $>10 \mu \mathrm{mol} / \mathrm{l}\left(\mathrm{p}<0.001 \mathrm{R}_{1}\right.$ to $\mathrm{R}_{2}$

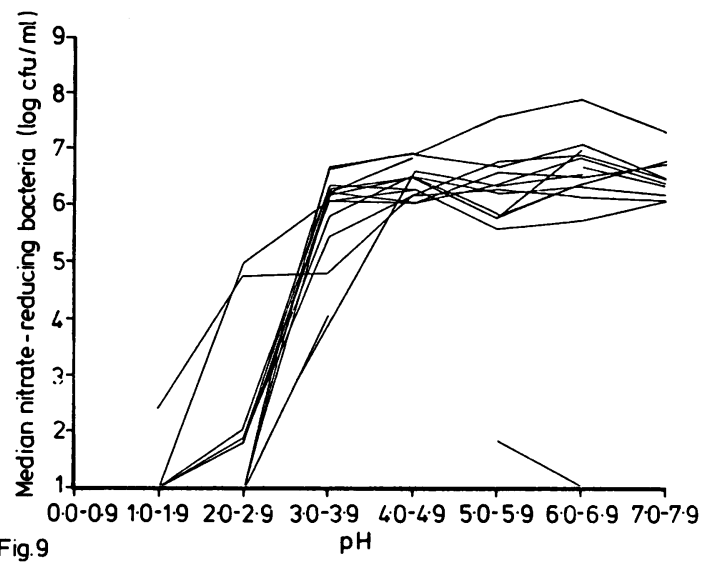

Fig. 9 Comparison between median nitrate reducing bacterial counts and $\mathrm{pH}$ range of individual patients at each study $R_{1}-R_{5}$ Each line represents an individual patient. $r_{\text {median }}=0.47 p<0.001$. 
and $p=0.008 R_{1}$ to $R_{4}$; Fig. 6). There was no significant difference in 24 hour summary values between $R_{1}$ (before treatment) and $R_{5}$ (after finishing one year of treatment). Median nitrite concentration in gastric aspirates after vagotomy $(2.2 \mu \mathrm{mol} / \mathrm{l})$, and percentage of aspirates with concentration $>10$ $\mu \mathrm{mol} / \mathrm{l}(13 \%)$, were lower than the corresponding values recorded during maintenance treatment with ranitidine $\left(R_{3}\right.$ median $4 \cdot 2,32 \%>10 \mu \mathrm{mol} / \mathrm{l} ; \mathbf{R}_{4}$ median $5 \cdot 1,33 \%>10 \mu \mathrm{mol} / \mathrm{l}$ ), but formal comparison between $\mathbf{R}_{4}$ and vagotomy showed that neither these differences, nor those relating to night time samples alone, were statistically significant $(p>0 \cdot 05)$. Nitrite concentration correlated positively with $\mathrm{pH}$ in the ranitidine group $\left(\mathrm{r}_{\text {median }}=0.30\right.$, $\mathrm{p}<0.001$, Fig. 10) and after vagotomy $\left(r_{\text {median }}=0 \cdot 19\right.$, $\mathrm{p}<0 \cdot 001$ ).

\section{N-NITROSO COMPOUNDS}

For reasons explained above, gastric aspirates were not tested for $\mathrm{N}$-nitroso compounds during study $\mathrm{R}_{2}$, at night during the other studies or when insufficient juice was present. Consequently results for these compounds are based on analysis of 465 out of a possible 590 day time $(1200-2100 \mathrm{~h})$ samples in 59 studies. There was no change between the median of

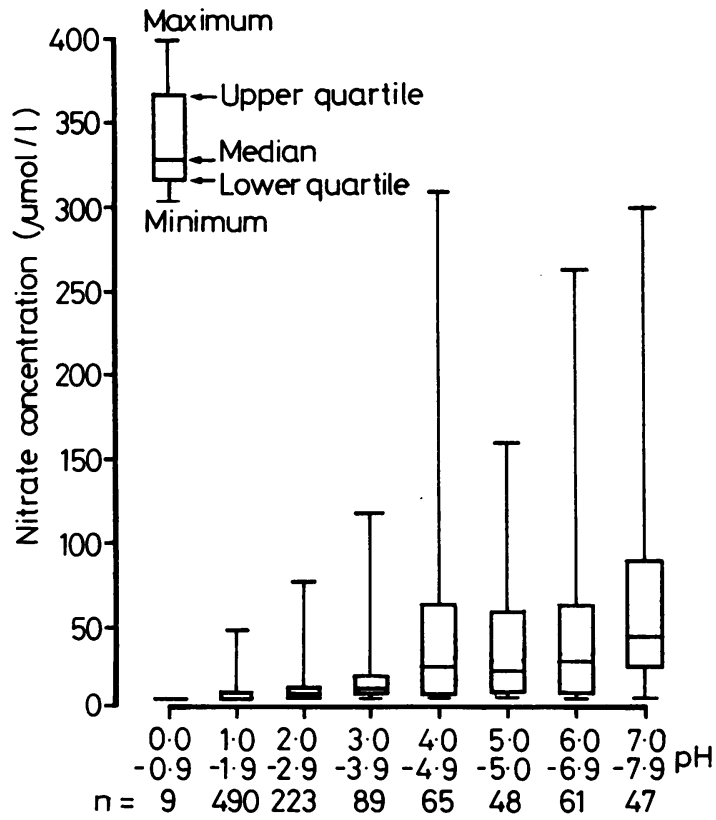

Fig. 10 Box plot comparison between nitrate concentration and $\mathrm{pH}$ range in paired data pooled from studies $R_{1}-R_{5} n$ represents number of paired observations in each $p H$ range. $r_{\text {median }}=0.30 p<0.001$. the median day time $\mathrm{N}$-nitroso compound concentrations recorded in $R_{1}$ and $R_{4}$ (Fig. 7) and the decrease seen in the median percentage of samples containing $>500 \mathrm{nmol} / \mathrm{l} \mathrm{N}$-nitroso compounds was not quite statistically significant $(p=0 \cdot 07)$. Median summary values of $\mathrm{N}$-nitroso compounds did not change significantly between studies $R_{1}$ and $R_{5}$. Median summary values recorded after vagotomy (median concentration $260 \mathrm{nmol} / 1,33 \%>500 \mathrm{nmol}$ ) were similar to those recorded in studies $\mathbf{R}_{\mathbf{3}}(330$ $\mathrm{nmol} / \mathrm{l}, 40 \%)$ and $\left.\mathrm{R}_{4}(253 \mathrm{nmol} / \mathrm{l}), 13 \%\right)$; statistical comparison between $R_{4}$ and vagotomy showed no significant differences $(p>0.05)$. There was no correlation between intragastric $\mathrm{pH}$ and $\mathrm{N}$-nitroso compound concentration either in the ranitidine group $\left(r_{\text {median }}=0.03, p=0.61\right.$, Figs. 11,12$)$ or after vagotomy $\left(r_{\text {median }}=-0.13, p=0 \cdot 23\right)$ nor between nitrite and $\mathrm{N}$-nitroso compound concentrations (ranitidine group $r_{\text {median }}=0.23, p=0.06$; following vagotomy $r_{\text {median }}=0 \cdot 10, p=0 \cdot 29$ ).

\section{NITRATE CONCENTRATION}

Twenty four hour median nitrate concentrations for individual patients varied between $<0.005-1.540$ $\mathrm{mmol} / \mathrm{l}$; the overall median of median nitrate concentrations (mmol/l) in each study was: $R_{1} \mathbf{0 . 4 9 5}, R_{2}$ $0 \cdot 485, R_{3} 0 \cdot 340, R_{4} 0 \cdot 245, R_{5} 0 \cdot 347$, pre-vagotomy 0.520 and postvagotomy 0.420 . The median percentage of samples in each study with nitrate concentration $>0.2 \mathrm{mmol} / \mathrm{l}$ varied thus: $R_{1} 93 \%, R_{2} 87 \%, R_{3}$ $81 \%, R_{4} 72 \%, R_{5} 89 \%$, pre-vagotomy $95 \%$ and postvagotomy $90 \%$.

\section{NITRATE ENRICHED DIET}

Separate comparisons between summary data recorded in $R_{1}$ and $R_{4}$ in patients given the standard diet and those given the nitrate enriched diet showed no significant difference between the two groups for any variable $(\mathrm{p}>0.05)$.

\section{Discussion}

Twenty four hour experiments entail important methodological problems in certain areas, which in this study have been approached as follows.

Data from each study were reduced to summary values in order to reflect the gastric juice composition at each stage of treatment and permit comparisons to be made between stages of treatment with ranitidine and between prolonged maintenance treatment with ranitidine and vagotomy. Inevitably, hour-to-hour variations among individual patients, which are possibly as interesting as global changes, are obscured by compression of data into summary values. While such detailed analysis is theoretically desirable, without collation and summarising no meaningful 


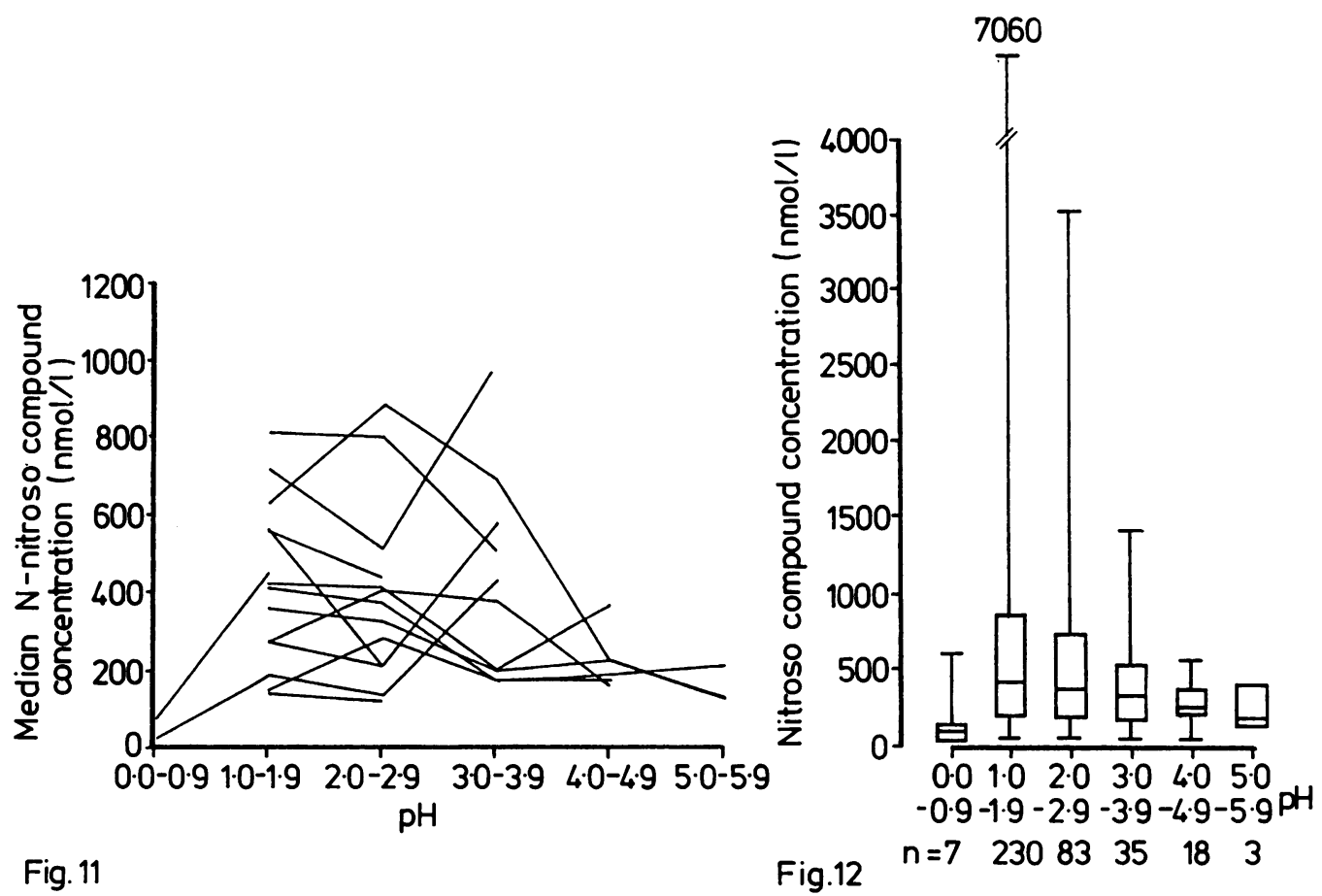

Fig. 11 Comparison between median $N$-nitrosocompound concentration and $p H$ range of individual patients at each study $R_{l}, R_{3}, R_{4}, R_{5}(1200-2100 \mathrm{~h})$ Each line represents an individual patient. $r_{\text {median }}=-0.03 \mathrm{p}=0.61$.

Fig. 12 Box plot $^{39}$ comparison between $N$-nitrosocompound concentration and $p H$ range in paired data pooled from studies $R_{l}, R_{3}, R_{4}, R_{5}(1200-2100 \mathrm{~h}) \mathrm{n}$ represents number of paired observations in each $p H$ range. $r_{\text {median }}=-0.03 p=<0 \cdot 61$.

analysis of the vast amount of data collected could have been made.

The cut off levels selected as the limits of clinical significance are based on the limited published data pertaining to the variables studied. They are to some extent however, arbitrary, as 'normal' levels are not known precisely: results expressed in relation to these cut off levels must, therefore, be interpreted with caution. In particular, what constitutes an abnormal concentration of $\mathrm{N}$-nitroso compounds is quite unknown: their concentration rises after meals, so we have almost certainly been over cautious in choosing the upper limit of 'normal' fasting concentration (albeit measured by an alternative method) as the threshold of abnormality.

In some respects this investigation of treatment with ranitidine for one year was uncontrolled, as (for obvious reasons) patients with peptic ulcer were not studied for a year without treatment. Comparisons between studies $R_{1}$ and $R_{5}$ (before and after medical treatment), however, provide within patient control data. The ranitidine and vagotomy groups did not arise as a result of a randomised allocation of peptic ulcer patients. The patients in the vagotomy group may not be strictly comparable with those given ranitidine because they had ulcers which needed vagotomy after the failure of medical treatment. This difference is probably more apparent than real for these are the very patients who, if long term treatment is deemed to be safe, might in the future be managed by prolonged administration of histamine $\mathrm{H}_{2}$-antagonist drugs. Nevertheless, in view of these limitations of the study, all tests of statistical significance must be interpreted with some caution.

A diet similar to the standard diet used in this study was used in previous studies involving 24 hour sampling of gastric juice. Investigations to determine whether such a diet provides sufficient nitrate as substrate for bacterial reduction to nitrite and subsequent nitrosation had, however, not been carried out. As gastric cancer has been linked with consumption of nitrate in food and drinking water in high nitrate areas of England ${ }^{34}$ and Colombia, ${ }^{35}$ in the present study half of the diets were enriched with nitrate $300 \mathrm{mg}$ daily to mimic the high nitrate content typical of a predominantly salad diet. Significant increases in nitrite, or N-nitroso compound concentrations were not detected in those receiving added 
nitrate compared with those on a conventional diet. This suggests that the standard 24 hour diet as used in this and other investigations does contain sufficient nitrate for ultimate nitrosation.

Because of the overriding need to be certain that ranitidine present in gastric juice would not be assayed as if it were a $\mathrm{N}$-nitroso compound, aspirates of juice were only used for $\mathrm{N}$-nitroso compound analysis at times when ranitidine was absent. Results for N-nitroso compounds are consequently based on assay of approximately one third of the samples that were analysed for $\mathrm{pH}$, bacterial counts and nitrite concentration; conclusions must be correspondingly less certain, especially as no night-time samples were studied. N-nitroso compounds were not measured at all during study $R_{2}$ but no increase in day time median values was found during $\left(R_{3}\right.$ and $\left.R_{4}\right)$ or after $\left(R_{5}\right)$ maintenance treatment, an observation in agreement with other 24 hour studies. ${ }^{1516}$

There has been considerable debate on the relative merits of measuring $\mathrm{N}$-nitroso compounds with the speed of the method of Bavin et al,,$^{33}$ or of measuring the more stable compounds, with greater specificity using the method described by Walters et al ${ }^{24}$ We elected to use the latter method. Until now Bavin's technique had been used in 24 hour studies while Walters' method has only been used on fasting gastric juice. Perhaps as a result of these different study conditions or of the different analytical methods, conclusions concerning the correlation of $\mathrm{N}$-nitroso compound concentrations with $\mathrm{pH}$ and with treatment using histamine $\mathrm{H}_{2}$-receptor antagonists or vagotomy have differed in various studies. Studies of fasting gastric juice ${ }^{12}{ }^{13}$ have concluded that $\mathrm{N}$-nitroso compound concentrations are increased in the presence of hypoacidity achieved by $\mathrm{H}_{2}$-blockade using cimetidine. The present results, however, agree with data from other 24 hour studies ${ }^{151636}$ (in which gastric juice samples were also stabilized using hydrazine at $\mathrm{pH} 4 \cdot 0$ ), in showing that there is no correlation between $\mathrm{pH}$ and concentrations of $\mathrm{N}$ nitroso compounds derived from food and gastric juice. Day time concentrations of these compounds did not increase with histamine $\mathrm{H}_{2}$-receptor blockade at maintenance dosage, or after vagotomy. Hall et a $l^{37}$ found a negative correlation between $\mathrm{pH}$ and $\mathrm{N}$ nitroso compound concentration in patients investigated by 24 hour studies after gastric surgery. The relationship in the present study between $\mathrm{pH}$ and $\mathrm{N}$ nitroso compound concentration for individual patients shown in Figure 11 reflects the lack of significant correlation, but demonstrates a tendency to an inverse relationship, confirmed by statistical analysis. Figure 12, giving data for all the patients combined, strongly suggests a genuine inverse relationship between $\mathrm{pH}$ and $\mathrm{N}$-nitroso compound concentration, if allowance is made for the scarcity of samples in the $\mathrm{pH}$ range $0-0.9$.

The present results agree generally with other 24 hour studies which investigated effects of cimetidine $^{1516}$ and vagotomy: ${ }^{36} \mathrm{pH}$ correlated positively with nitrate concentration and with $\mathrm{TB}$ and NRB counts. Twice daily treatment with ranitidine $150 \mathrm{mg}$ was associated in the present investigation with significant increases of $\mathrm{pH}$, nitrite concentration and TB and NRB counts, while during night-time maintenance dosage $(150 \mathrm{mg}) \mathrm{pH}$ and nitrite concentrations were raised. Day time concentrations of $\mathrm{N}$ nitroso compounds arising from food and gastric juice precursors were not raised during maintenance treatment with ranitidine; the tendency to a negative correlation between $\mathrm{pH}$ and concentration of $\mathrm{N}$ nitroso compounds found in the present data and those of Milton-Thompson et al ${ }^{15}$ suggests that $\mathrm{N}$ nitroso compound concentrations would probably not increase during the more marked rise in $\mathrm{pH}$ found at night and during twice daily treatment with ranitidine.

After truncal vagotomy intragastric conditions did not differ significantly from those recorded during maintenance treatment with ranitidine. Twenty four hour study of patients before and after vagotomy was only possible on three subjects, preventing calculation of meaningful summary values, or formal analysis of changes occurring as a result of surgery. Changes observed in these patients, however (data available on file), were similar to changes seen . between studies on patients before $\left(R_{1}\right)$ and during maintenance treatment $\left(R_{4}\right)$ with ranitidine.

The absence of significant differences during the day between the vagotomy group and study $R_{4}$ of the ranitidine group is readily apparent from perusal of Figures 3-6. At night, however, graphical display suggests that there were marked differences, with values after vagotomy being less than those after prolonged maintenance treatment with ranitidine. The graphs display hour-by-hour differences for all patients combined (as median values); when hourly values at night are combined into summary values for each patient, and the two groups compared using the two sided Wilcoxon's rank-sum-test, only total bacterial counts were significantly higher in the ranitidine group. Of the seven variables compared between the two studies for night time samples, all comparisons had $\mathrm{p}$ values less than $0 \cdot 20$ : the tendency was for higher responses in the ranitidine treated group, but only TB achieved a significant difference at the conventional $5 \%$ level. For the 24 hour data, however, all seven $p$ values were greater than $0 \cdot 20$.

It has been stated that high counts of bacteria have been infrequent, sporadic, and rarely recorded in consecutive samples, ${ }^{15}$ but the relative importance of 
the high peaks compared with prolonged but moderately raised bacterial counts is not known. Data presented here show that for several hours during each 24 hour period an acid tide renders nitrate reducing bacteria undetectable and prevents colonisation by either oropharyngeal or faecal organisms. An investigation of different types of vagotomy $^{36}$ showed that a resident bacterial flora was established only after truncal vagotomy and antrectomy. It is possible that inhibition of acid secretion with agents more potent than ranitidine or truncal vagotomy may result in a resident (even faecal type) bacterial flora.

For example, Sharma et $\mathrm{l}^{38}$ reported that 22 hours after a dose of omeprazole, fasting $\mathrm{pH}$, bacterial counts, percentage of bacteria that were NRB, nitrite and $\mathrm{N}$-nitroso compound concentrations were all significantly higher than before treatment.

The most important findings of this study are that despite increase in $\mathrm{pH}$, high counts of NRB and nitrite concentration, $\mathrm{N}$-nitroso compound concentration did not increase during prolonged maintenance treatment with ranitidine and no significant change in any variable occurred between median values obtained before starting and one month after completing a year's maintenance treatment.

The fact that changes in $\mathrm{N}$-nitroso compound concentration did not parallel changes in $\mathrm{pH}$, bacterial counts and nitrite concentration, taken together with the lack of formal correlation between $\mathrm{pH}$ and $\mathrm{N}$-nitroso compound concentration, suggests that bacterially catalysed nitrosation at more alkaline $\mathrm{pH}$ may be less biologically important than chemically catalysed nitrosation (which proceeds best at $\mathrm{pH}$ $1 \cdot 0-3 \cdot 0$ ) when periods of hypoacidity are of short duration. Implications for the nitrosamine hypothesis of gastric carcinogenesis are difficult to specify since persistent colonisation of the stomach was not encountered. It is possible, within the framework of the hypothesis, that alternating periods of reduced and normal acidity are accompanied by bacterial multiplication and nitrite formation when the $\mathrm{pH}$ is raised, followed by nitrosation when $\mathrm{pH}$ falls. Alternatively it may be that carcinogens other than $\mathrm{N}$-nitroso compounds are important or that, at the level of the epithelial cell, even the very small concentrations of $\mathrm{N}$-nitroso compounds produced at alkaline $\mathrm{pH}$ may be carcinogenic in the presence of reduced acidity, gastritis or dysplasia.

We wish to thank many colleagues for their help in the clinical and laboratory aspects of the study; Mr N Menzies-Gow for permission to study his vagotomy patients, Drs Hui Wai Mo and N Shaub, Central Middlesex Hospital; Mr C Gooding, Miss D Nolan, Miss K Wightman, PHLS Porton Down; Miss A
Stripp, Food Research Association Leatherhead; Dr $\mathrm{J}$ Hare, $\mathrm{Mr} \mathrm{C}$ Harrison, Glaxo Group Research. It is a pleasure to acknowledge the great deal of time consuming effort provided by this paper's two anonymous reviewers, whose detailed constructive criticism has made a substantial contribution to its final content. Finally, we are grateful to Miss B M E Shambrook and Mrs R Cockburn for typing the manuscript.

\section{References}

1 Siurala M, Lehtola J. Ihamäki T. Atrophic gastritis and its sequelae. Results of 19-23 years follow-up examinations. Scand J Gastroenterol 1974; 9: 441-6.

2 Blackburn EK, Callender ST, Dacie JV, et al. Possible association between pernicious anaemia and leukaemia: a prospective study of 1625 patients with a note on the very high incidence of stomach cancer. Int $J$ Cancer 1968; 3: 163-70.

3 Walker IR, Strickland RG, Ungar B, Mackay IR. Simple atrophic gastritis and gastric carcinoma. Gut 1971; 12: 906-11.

4 Stalsberg H, Taksdal S. Stomach cancer following surgery for benign conditions. Lancet 1971; ii: 1175-7.

5 Nicholls JC. Carcinoma of the stomach following partial gastrectomy for benign gastroduodenal lesions. $\mathrm{Br} \mathrm{J}$ Surg 1974; 61: 244-9.

6 Domellöf L, Janunger K-G. The risk of gastric carcinoma after partial gastrectomy. Am J Surg 1977; 134: 581-4.

7 Ellis DJ, Kingston RD, Brookes VS, Waterhouse JAH. Gastric carcinoma and previous peptic ulceration. $\mathrm{Br} J$ Surg 1979; 66: 117-9.

8 Haukland H, Johnson JA. Gastric cancer after vagotomy and excision for gastric ulcer. Eur Surg Res 1981; 13: 371-5.

9 Totten J, Burns HJG, Kay AW. Time of onset of carcinoma of the stomach following surgical treatment of duodenal ulcer. Surg Gynecol Obstet 1983; 157: 431-3.

10 Correa P, Haenszel W, Cuello C, Tannenbaum S, Archer M. A model of gastric cancer epidemiology. Lancet 1975; ii: 58-60.

11 Ruddell WSJ, Bone ES, Hill MJ, Blendis LM, Walters CL. Gastric juice nitrite; a risk factor for cancer in the hypochlorhydric stomach. Lancet 1976; ii: 1037-9.

12 Reed PI, Smith PLR, Haines K, House FR, Walters CL. Effect of cimetidine on gastric juice $\mathrm{N}$-nitrosamine concentration. Lancet 1981; ii: 553-6.

13 Stockbrugger RW, Cotton PB, Eugenides N, Bartholomew BA, Hill MJ, Walters $\mathrm{CL}$. Intragastric nitrites, nitrosamines and bacterial overgrowth during cimetidine treatment. Gut 1982; 23: 1048-54.

14 Muscroft TJ, Youngs DJ, Poxon VA, et al. Hypochlorhydria, bacteria, nitrite and nitrosamines in gastric juice [Abstract]. Br J Surg 1980; 67: 817.

15 Milton-Thompson GJ, Lightfoot NF, Ahmet Z, et al. Intragastric acidity, bacteria, nitrite and N-nitroso compounds, before, during and after cimetidine treatment. Lancet 1982; i: 1091-5. 
16 Barnard J, Darkin DW, Howard OM, Lightfoot NF, Milton-Thompson GJ, Viney NJ. N-Nitroso compounds in cimetidine-treated duodenal ulcer patients. [Abstract]. Gut 1983; 24: A974.

17 Walt RP, Male P-J, Rawlings J, Hunt RH, MiltonThompson GJ, Misiewicz JJ. Comparison of the effects of ranitidine, cimetidine and placebo on the 24 hour intragastric acidity and nocturnal acid secretion in patients with duodenal ulcer. Gut 1981; 22: 49-54.

18 Lim CC, Forster JK, Jackson JL, Robinson WD, Tracey LE. Ranitidine in duodenal ulcer: an international collaborative study. Am J Gastroenterol 1981; 76: 183.

19 Lee FI, Fielding JD, Mackay C, et al. Comparison of twice daily ranitidine and placebo in the treatment of duodenal ulcer - a multicentre study in the United Kingdom. Hepatogastroenterology 1982; 29: 127-9.

20 Boyd EJS, Wilson JA, Wormsley KG. Maintenance treatment of duodenal and gastric ulcer with ranitidine. In: Riley AJ, Salmon PR, eds. Ranitidine: Proceedings of an International Symposium held in the Context of the Seventh World Congress of Gastroenterology. Amsterdam: Excerpta Medica, 1982: 102-16.

21 Gough KR, Korman MG, Bardhan KD, et al. Ranitidine and cimetidine in prevention of duodenal ulcer relapse. Lancet 1984; ii: 659-62.

22 Faber RG, Russell RCG, Parkin JV, Whitfield P, Hobsley $M$. The predictive accuracy of the post vagotomy insulin test: a new interpretation. Gut 1975; 16: $337-42$.

23 Cox RD. Determination of nitrate and nitrite at the parts per billion level by chemiluminescence. Anal Chem 1980; 52: 332-5.

24 Walters CL, Downes MJ, Edwards MW, Smith PLR. Determination of a non-volatile $\mathrm{N}$-nitrosamine on a food matrix. Analyst 1978; 103: 1127-36.

25 Borriello $\mathbf{P}$, Hudson $\mathbf{M}$, Hill $\mathbf{M}$. Investigation of the gastrointestinal bacterial flora. Clin Gastroenterol 1978; 7: 329-49.

26 Cowan ST, Steel KJ. Manual for the identification of medical bacteria. London: Cambridge University Press, 1974: 176-7.

27 Meynell GG, Meynell E. Theory and practice in experi- mental bacteriology. Cambridge: Cambridge University Press, 1965: 231.

28 Bartholomew B. A rapid method for the assay of nitrate in urine using the nitrate reductase enzyme of Escherichia Coli. Food Chem Toxicol 1984; 22: 541-3.

29 Jenner WN, Martin LE, Willoughby BA, Fellows I. The development of a radioimmunoassay for ranitidine in biological fluids. Life Sci 1981; 28: 1323-9.

30 Hill MJ. Nitrates and Bacteriology: Are these important etiological factors in gastric carcinogenesis? In: Fielding JWL, et al, eds. Proceedings of an International Symposium on Gastric Cancer, Birmingham, September 1980. Advances in the biosciences; gastric cancer. Pergamon, 1981; 32: 35-45.

31 Drasar BS, Hill MJ. Human intestinal flora. London: Academic Press, 1974: 72-102.

32 Jones SM, Davies PW, Savage A. Gastric juice nitrite and gastric cancer. Lancet 1978; i: 1355.

33 Bavin PMG, Darkin DW, Viney NJ. Total nitroso compounds in gastric juice. In: Bartsch $\mathrm{H}$, O'Neill IK, Castegnaro $\mathrm{M}$, Okada $\mathrm{M}$, eds. $N$-nitrosocompounds: occurrence and biological effects. Lyon: IARC Scientific Publications, 1982: 337-44.

34 Hawksworth G, Hill MJ. Bacteria and the N-nitrosation of secondary amines. Br J Cancer 1971; 25: 520-6.

35 Correa P, Cuello C, Duque E, et al. Studies of gastric cancer in Colombia. III. Natural history of precursor lesions. J Natl Cancer Inst 1976; 57: 1027-35.

36 Keighley MRB, Youngs D, Poxon V, et al. Intragastric $\mathrm{N}$-nitrosation is unlikely to be responsible for gastric carcinoma developing after operations for peptic ulcer. Gut 1984; 25: 238-45.

37 Hall CN, Darkin D, Brimblecome R, et al. Evaluation of the nitrosamine hypothesis of gastric carcinogenesis in precancerous conditions. Gut 1986; 27 : 491-8.

38 Sharma BK, Santana IA, Wood EC, et al. Intragastric bacterial activity and nitrosation before, during, and after treatment with omeprazole. Br Med J 1984; 289: 717-9.

39 Tukey JW. Exploratory data analysis. Reading, Mass: Addison-Wesley Publishing Co, 1977: 27-56. 